\title{
INSTITUTIONS FOR THE ADMINISTRATION OF VILNIUS AT THE BEGINNING OF THE GERMAN OCCUPATION DURING THE FIRST WORLD WAR
}

\author{
Edmundas Gimžauskas
}

ABSTRACT The entrenched opinion in historiography is that during the First World War, the German army, after entering the lands belonging to the Russian Empire, created its own occupying administrative structures essentially in an empty space. This also applies to the case of Vilnius. Nevertheless, the diaries and memoirs of witnesses of the events of that time cast doubt on this very entrenched stereotype. Indeed, the entry of the Germans into Vilnius in September 1915 meant radical changes in the development of the city's administration, but from an administrative point of view, the arriving conquerors did not really find an empty space here. Certain structures, the city magistrate, police and Citizens' Committee were approved for retention. This was done not at the initiative of the Russian government that carried it out, but of the local public itself. After the Germans marched in, they did not destroy the structures of civil administration they found, but adapted them to meet their own interests. Along with this, they created military structures, leaving civilian rule on the sidelines. As the Germans gradually established themselves, the rudiments of occupation civilian rule, which were drawn from cadres of local Poles, began to emerge. This was associated with the trend the German authorities expressed in the first months of the occupation to link the future of the Vilnius region with Poland. The Poles of Vilnius, dominating in the structures of the civil administration, hoped for a liberal system of government, similar to that of occupied ethnic Poland. However, in the late autumn of 1915, at the initiative of the highest German military command in the East, a special administrative formation, the Oberost, began to be created, which was to become an economic and military colony of Germany. The Vilnius region was also to be part of it. From then on, the creation of the German civil adminis- 
tration began on a purely military basis, with the suppression of the Polish identity and the gradual restriction and pressure on all former local administrative structures, which was fully revealed at the beginning of 1916.

For a variety of reasons, almost throughout the whole 20th century, the period of the First World War in Lithuanian historiography remained one of the least studied areas. ${ }^{1}$ For a very long time, not a single detailed scholarly study was made specifically on this period, and only the book by Raimundas Lopata that appeared in 1996 was the first serious breakthrough in Lithuanian research into the period ${ }^{2}$. The section in it on 1914 to 1918 was looked at from the point of view of the development of the Lithuanian national movement and Lithuanian statehood; however, up to these days, many other aspects of the period (military, demographic, social history, etc) remain very poorly covered or not studied at all. The history of the administration of Lithuania and its individual regions and units in the war years would belong to such very poorly studied subjects. True, the most general administrative elements are inevitably touched on in synoptic, synthetic works, but this is usually done in a very incomplete and fragmentary way. The specific case of the Vilnius administration is also no exception here.

In this study, we intend to focus on the history of the governance of Vilnius from September 1915 to the first half of 1916, i.e. the period of the founding and entrenchment of the German administration. Since the period was critical (suddenly the highest government of the land changed, which began to create totally new administrative structures), we must surely also analyse what kind of heritage this new government found or took over, namely, the essential elements of the Russian administration. We should immediately pay attention to one fallacy of a very resilient historical stereotype: that allegedly the Germans created their own administrative structures in occupied Lithuania practically from nothing; that there was no period during which elements of the old and new rules coexisted. We perceive at least two origins to this myth, which later combined to influence

${ }^{1}$ For more information see: A. Eidintas, 'Lietuvių ir vokiečių santykių tyrinèjimai $\mathrm{XX}$ amžiaus lietuvių istoriografijoje (Apžvalgos bandymas)', Istorija kaip politika: juvkkiu raidos apžvalga (Vilnius, 2008), pp. 111-132.

${ }^{2}$ R. Lopata, 'Lietuvos valstybingumo raida 1914-1918 metais', Lietuviu atgimimo istorijos studijos (LAIS), t. 9 (Vilnius, 1996). 
Lithuanian historiography very strongly. First, the Germans themselves during the First World War and immediately after it began to emphasise that, having entered the occupied territory, they found an empty space where government was concerned: allegedly, the whole apparatus of the Russian administration had fled along with members of the local population, who, if they had remained, would have been at least competent in part to replace the Russians in the posts of the old apparatus. Chaos threatened, and the Germans consistently and legally began to restore order according to their understanding, customs and needs. ${ }^{3}$ In this way, the Germans tried to justify and argue their special administrative arrangement, by founding the Oberost, which from the very beginning of its existence received much deserved criticism from the humane part of the public for its cruel and exploitative nature. However, researchers such as the Swede Börje Colliander, ${ }^{4}$ who wrote on the theme in the interwar period, took up the tendentious German approach, and in this way it found the possibility to take root in the historiographical medium. Second, Soviet historiography after the Second World War behaved somewhat differently: it did not focus on the technical subtleties of the German administration, but stressed the fact that the occupiers had immediately torn down the whole old administrative apparatus and created their own new one. Juozas Žiugžda, in the multi-volume history of the Lithuanian SSR, wrote: 'The occupants from the very start liquidated all the former administrative bodies and judicial institutions in Lithuania, and established their own administration to manage and exploit the region. ${ }^{5}$ True, no one bothered to detail what the remaining bodies of administration after the withdrawal of the Russian army were. We see the same trend even in a collective monograph on the history of Vilnius published in the Soviet period. It writes: 'After the German army occupied Vilnius, the city was

${ }^{3}$ Das Land Ober Ost. Deutsche Arbeit in den Verwaltungsgebieten Kurland, Litauen und Bialystok-Grodno (Stuttgart, 1917), pp. 79-84; 'Das Gouvernement Wilna', Scheinwerfer. Bildbeilage zur Zeitung der 10. Armee, 1916, no. 10, pp. 2-3; R. Häpke, Die deutsche Verwaltung in Litauen 1915 bis 1918 (Berlin, 1921), p. 9, 22.

${ }^{4}$ B. Colliander, Die Beziehungen zwischen Litauen und Deutschland wahrend der Okkupation 1915-1918 (Abo, 1935), p. 29. Colliander's book is obviously missing a critical assessment of the German sources; despite this, for many years it was perhaps the only comprehensive study of a more general nature about the 1915-1918 period of Lithuanian history.

${ }^{5}$ Lietuvos TSR istorija, t. 2: Nuo 1861 iki 1917 metu, ed. J. Žiugžda (Vilnius, 1963), p. 421. 
subjected to a military occupation administration. The whole apparatus of the former Russian rule in Vilnius was liquidated. ${ }^{6}$ Paradoxically, in the case of both the German and the Soviet approach, the conclusion is the same: the Germans created their administration in an empty space. So it is simply difficult to overestimate the power and impact of the statement's inertia.

However, after reading the diaries of witnesses to the events and of contemporaries, a somewhat different view of the situation is formed. In those texts, speaking in particular about the events of late 1915 and early 1916, the concepts 'city Duma' and 'city board'7 often appear, i.e. the same institutions that functioned in the times of tsarist rule. Merely from that, it is evident that the Germans did not create their administration in an empty space, that the situation was much more complex and subtle than it is traditionally drawn in historiography. This would be a direct incentive, based on classic principles of historicism, to try to reconstruct a more detailed picture of the city administration during this period, seeking to prove convincingly the fallacy of the stereotypes discussed above; and also to shed a light on at least one very poorly known page of the city's history.

\section{The entry of the Germans into Vilnius}

We could start from the widely known fact that the German army occupied Vilnius on 5/18 September 1915. The military history of the occupation, in general terms, was that after the capture of the Kaunas fortress, a new joint attack by the German forces, the 'Vilnius operation', in which the Neman, 10th, 8th and 12th armies of Germany participated, began immediately. ${ }^{8}$ The main role fell to the 10th Army, which had to smash the 10th Army of Russia, which was defending Vilnius, and occupy the city. At the same time, the Neman army was instructed to occupy Daugavpils, and the 8th and

${ }^{6}$ J. Jurginis, V. Merkys, A. Tautavičius, Vilniaus miesto istorija: nuo seniausiu laiku iki Spalio revoliucijos (Vilnius, 1968), p. 376.

${ }^{7}$ P. Klimas, Dienoraštis 191512 01-1919 01 19, pradedamas P. Bugailiškio užrašais 19150823 (10)-1013 (Chicago, 1988), pp. 37, 42, 60, 62, 71 et al.; Cz. Jankowski, Z dnia na dzień. Warszawa 1914-1915 Wilno (Vilnius, 1923), pp. $275,277,304$ et al.

${ }^{8}$ For more information see: M. Pečiulis, 'Pirmojo pasaulinio karo veiksmai Lietuvos teritorijoje 1915 m. rugpjūčio pabaigoje - rugsèjo mènesį', Karo archyvas, 25 (2010), pp. 29-97. 
12th armies Grodno. On 8 September the main attack by the 10th Army began, also called the Švenčionys breakthrough, or simply the Battle for Vilnius. The Germans sought to circle the city from the north, and attack it from behind. Russia, pooling its forces, left a space between Pabradè and Dūkštas. Using this, the German forces pushed the Russian 5th Army northeast, occupied Švenčionèliai railway station, and invaded the territory of current Belarus. The military authorities of Russia, fearing the encirclement of the forces located in Vilnius, on 17 September began a withdrawal from the city. ${ }^{9}$ So the Germans entered Vilnius itself without a battle, which, in turn, also had an impact on the administrative aspect.

The retreating Russian army poured through the city during the whole night of 18 September until the early hours (most institutions and offices had withdrawn, already evacuated before then). The Russian police had already moved out around midnight. After the last organised Russian soldiers departed, as the authors of memoirs note, and 'historic moment' began: the city for several hours (from 6 to 9 o'clock in the morning) was under the rule of its own population. ${ }^{10}$ To witnesses of events, that government was associated most with the city's police guards deployed in the streets; therefore, it is also appropriate to look first at the history of the appearance of this institution.

In the summer of 1915 more and more doubts arose as to whether the Russians would be able to retain Vilnius, especially after the collapse of the Kaunas fortress. During the first few days of August, on the orders of the city Duma, the Civil Guard Organising Committee was created. ${ }^{11}$ It consisted almost entirely of attorneys practising in the city: Witold Abramowicz, Stanisław Bagiński, Józef Przyłuski, Jan Piłsudski; and also Józef Korolec. Feliks Zawadzki, a member of the famous dynasty of Vilnius printers and book dealers, became the chairman of the Committee. Guaranteeing public order and public security in the event of the expected withdrawal of the

${ }^{9}$ Ibid., p. 97.

10 Jankowski, Z dnia, p. 238; W. Łubieński, 'Wilno we wrześniu 1915 r.: kartki z pamiętnika sprzed 22 laty', Kurier Wileński, 8 IX 1937, no. 247, p. 3. Cz. Jankowski already in 1916 wrote about the withdrawal of the Russians from Vilnius and the arrival of the Germans in the journal Tygodnik illustrowany issued in Warsaw (Cz. Jankowski, 'Zdobycie Wilna', Tygodnik illustrowany, 1916, no. 11, pp. 123-124; no. 12, pp. 137-138; no. 13, pp. 149-150.).

11 'Straż Obywatelska w roku 1915. Wywiad u p. Feliksa Zawadzkego, prezesa b. Straży Obywatelskiej w Wilnie’, Słowo, 18 IX 1925, no. 212, p. 2. 
Russian government from the city became the Committee's concern. The plan began with the partition of the city into police districts; nine were envisioned. The candidates for commisioners of these were discussed. A recruitment campaign for the Citizens Guard, or policemen, was also immediately launched. As Zawadzki himself said, in a short time about 3,000 candidates registered. ${ }^{12}$

On the eve of the withdrawal of the Russians from the city, a joint meeting of the tsarist police and Citizens' Guard took place in the city hall of the Duma, at which it was decided that the Citizens' Guard would begin to take over the functions of the withdrawing police. ${ }^{13}$ Because the Russian government did not allow the members of the militia of the city to be armed until the last minute, their main weapons were truncheons, similar to those used by the British police. On the night of 17 to 18 September the city militia took over all the positions of the withdrawing Russian police, and by the morning they controlled fully public order in Vilnius. ${ }^{14}$ About 6 or 7 am their first contacts with the advance scouts of the German army began. We should just add here that the authors of diaries and memoirs do not have a unified opinion on the initiative for the creation of the Citizens' Guard and issues of command. For example, the famous Lithuanian figure Steponas Kairys says that 'the militia was organised by those working in the workers' organisations, the so-called "left". ${ }^{15}$ The Polish Democrat Zygmunt Jundziłł wrote that the city police were subordinate to the Citizens' Committee (Komitet Obywatelski). ${ }^{16}$

An important part of the German 10th Army was the 40th reserve corps, led by General Karl Litzmann (Litzmann's military group), which had been directly involved in the capture of the Kaunas fortress, and from there marched straight to Vilnius. ${ }^{17}$ The 14th Landwehr

12 Ibid.

13 Ibid.

${ }^{14}$ Ibid.; Klimas, Dienoraštis, p. 26 (comment from the notes of Peliksas Bugailiškis). Klimas himself also at that time had signed up as a Vilnius militiaman and described his impressions of the moment of the change (P. Klimas, Iš mano atsiminimu (Vilnius, 1990), pp. 39-42).

${ }^{15}$ S. Kairys, 'Nepriklausomybės akto išvakarèse', Kultūra, 1938, no. 2, p. 38. The historian Pranas Čepenas, relying on the opinion of Kairys, also repeated this in his book (P. Čepėnas, Naujuju laiku Lietuvos istorija, t. 2 (Vilnius, 1992), p. 26).

16 Z. Jundziłł, 'Z dziejów polskiej myśli politycznej na Litwie historycznej', Niepodległość, t. 6 (Londyn, 1958), p. 64.

${ }^{17}$ Pečiulis, 'Pirmojo pasaulinio karo veiksmai', pp. 66-67, 82; V. Doniela, 'Vilniaus kritimas 1915 metais', Paštas ir filatelija Lietuvoje, no. 43 (1999), pp. 79-83. 
(secondary reserve) Division, which marched towards Vilnius along the north bank of the River Neris, was sent to support him after battles in Poland after 30 August. ${ }^{18}$ The main component of this division was the Pfeil Brigade, consisting of one regiment of the Saxon 101st Landwehr (at that time the regiment was divided into two, the 101st and 103rd Saxon Landwehr regiments). The honour of being the first to march into Vilnius fell to this formation. According to the testimony of the Germans, on the day of the occupation of the city the brigade moved along the road from Maišiagala at 5:30 am. At 7:30 am the avant-garde reached the suburb of the Jews. ${ }^{19}$ The famous Polish figure Wincenty Lubieński described in his memoirs how the Germans, having come from Šnipiškès, crossed the Green Bridge into the centre of the city. ${ }^{20}$ The bridge was damaged by the retreating Russian soldiers, it had to be repaired for normal use. Meanwhile, the Germans threw several planks over the few metres of blown-up section of the bridge, and the first group of soldiers, without hesitation, crossed over to the other side of the river. In this group was the commander of the brigade, Colonel Traugott Pfeil, ${ }^{21}$ who, with a pistol in his hand, boldly went forward, although it was not at all clear how far the Russian troops had retreated. Lubieński specifically mentions that Colonel Pfeil came namely with the soldiers of the 101st Saxon Regiment.

More numerous units of the German army began to move into the city from $10 \mathrm{am}$, across the hastily repaired Green Bridge, but mainly across Žvėrynas bridge directly on to St George's Avenue. ${ }^{22}$ The army grew constantly, and moved in an uninterrupted stream eastwards through Vilnius for at least a few days. By noon on 18 September, 18, Colonel Pfeil and two adjutants had already arrived

${ }^{18}$ Doniela, 'Vilniaus kritimas', pp. 81-83.

${ }^{19}$ G. von der Gebelentz, 'Die "Gespenster" in Wilna', Scheinwerfer. Bildbeilage zur Zeitung der 10. Armee, 1916, no. 10, p. 1.

${ }^{20}$ Łubieński, 'Wilno we wrześniu', pp. 3-4.

${ }^{21}$ Pfeil und Klein-Ellguth Traugott (1860-1920), from an old Silesian aristocratic family, count, colonel of Saxony's military contingent, after 1915 also receiving the rank of general. Led the brigade of his name, distinguished himself in the battles capturing the Novogeorgijevsk fortress in Poland in 1915 before the brigade was transferred near Vilnius. He is most widely known for the famous 'Pfeil proclamation' in Vilnius, but in historiography he is not properly identified, confused with other persons.

22 Jankowski, $Z$ dnia, pp. 239-240. 
by car at the Vilnius magistrate. ${ }^{23}$ The head of the city Duma and Board (the mayor) Michal Węsławski, members of the Board, some Duma members and influential city residents met him. In this first dialogue with the new masters of the situation, the famous lawyer and cultural figure Tadas Wróblewski, ${ }^{24}$ who that time did not even formally belong to the city government, ${ }^{25}$ represented the assembed local people. He spoke French with Colonel Pfeil. In response to the latter's question, what is this land, Wróblewski replied that the answer could not be unequivocal: the Poles had brought Christianity and culture to this land, but lately it had been Russian, and Polishness was persecuted. To this, the German commander cheerfuly replied that the speaker was noted for the attributes of a gifted politician. ${ }^{26}$ The colonel had already brought to the meeting the German text of a proclamation to the inhabitants of Vilnius, which he ordered to be immediately translated into the Polish language; he listened to how it was translated, showing that he understood Polish. ${ }^{27}$ Then after ordering it to be translated into Russian, and in a few hours printed and put up in the city, he departed. He stayed at the St George Hotel. Meanwhile, representatives of the magistrate, having taken over the Russian habit of delaying and procrastination, did not comply with the order before the deadline. Moreover, they were unable to find the original German text for the arriving representative of Pfeil. Becoming very angry, he threatened the city with retributions for sabotaging the order; nevertheless, he gave a new deadline for its implementation. ${ }^{28}$ This time, the demand of the Germans was promptly executed, but again not very successfully: the proclamation was printed in a very small format; moreover, in the Russian translation there was an error of a rather ambiguous nature. Pfeil commanded the proclamation to be reprinted in a larger format and letters. In the evening, he invited representatives of the people of the city to visit him. This time, the conversation was not as pleasant as the first one. The colonel said he would have to take

${ }^{23}$ Ibid., p. 242; A. Szklennik, Dziennik 1915-1918 (rękopis), LCVIA, f. 1135, ap. 4 , b. $31,1.55$.

${ }^{24}$ Szklennik, Dziennik, 1. 56.

${ }^{25}$ T. Wróblewski was the legal consultant of the magistracy.

${ }^{26}$ Szklennik, Dziennik, 1. 56.

27 Ibid., 1. 57. One is talking about the famous 'Pfeil proclamation', which researchers into the history of Lithuania and the surrounding region in the period of the First World War mention very frequently in their works.

${ }^{28}$ Jankowski, Z dnia, p. 243. 
several representatives of the city as hostages. Mayor Węsławski himself, as well as members of the magistrate Ksawery Zubowicz and Adam Rymsza, ${ }^{29}$ were taken. Although the hostages were released very quickly, this whole event became a certain 'first cold shower' for the society of the city in its relations with the newly arrived Germans.

\section{The role of the city magistrate}

Who then was the magistrate of Vilnius, with whose representatives the Germans forged contacts, and what could its theoretical and practical competences be in that complicated moment for the city? On the eve of the First World War, Vilnius' government was based on the 1870 law on cities in Imperial Russia, which came into effect in the Northwest Region in $1876 .{ }^{30}$ From that year the institution of government (magistrate) of the new era appeared in Vilnius, which consisted of the Duma (City Council), the Board, and the head of the city, the mayor. The Duma was elected for a four-year term, and the Board and the mayor were elected from its members for the same duration. The Board initially consisted of six members, half of whom had to be re-elected every two years. The law initially provided for a maximum of 72 Duma members; due to various legislative amendments, it was not definitively established up to the very beginning of the war. The electors of the Duma had to meet four criteria: to be citizens of Russia, to be 25 years of age, not to be in debt to the city, and to be owners of property, taxed for the needs of the city. The latter property qualification was the most important. It determined that the city, with a population of about 180,000 , only had about 300 people with the right to elect the city's Duma. ${ }^{31}$ So to speak about the democracy of these elections is highly problematic. In addition, the right to participate in the elections was not granted at all to Jews. Moreover, the magistrate was constantly under the strict supervision of the tsar's state administration, in particular the governor. The governor oversaw the entire procedure of the elections, he could constrain and limit the activities of the magistrate, not approve candidates, and so on, for any pretext.

${ }^{29}$ Ibid., pp. 243, 245.

${ }^{30}$ I. Jaworski, Zarys dziejów Wilna (Vilnius, 1929), p. 22.

${ }^{31}$ J. Wałdoch, 'Wybory do Rady miejskiej i Zarządu miejskiego miasta Wilna w latach 1905-1913', Miscellanea Historico-Iuridica, t. XI (2012) pp. 256-257. 
Nevertheless, in the period up to the war, in the development of the elections and functioning of the magistrate, manifestations of democratisation constantly increased. In particular, the 1905 Revolution and the liberalisation of the system of the whole tsarist government related to it served this. In September 1905, Węsławski was elected as the new head of the city Duma, and he was the first Pole in the post after a 43 -year break. ${ }^{32}$ This was very well received in the Polish society of the city, and provided an incentive to engage actively in municipal affairs. There was diligent and enthusiastic preparation for the 1909 elections, the electorate, whose numbers already exceeded a thousand, was expanded, and Jews were also allowed to be Duma members, only they were not elected but appointed by the governor, after defining in the law that Jews could not comprise more than 10 per cent of the composition of the Duma. ${ }^{33}$ On the basis of programmes already competed for in the elections, two blocks of representatives of the Polish public, in fact, made at the same time an informal agreement directed against the Russian candidates. Fifty-six Polish and nine Russian representatives entered the 1909 Duma by way of elections, and seven Jewish representatives were appointed. ${ }^{34}$ Węsławski again became the head of the magistrate. The 1913 electoral campaign was calmer and more objective than previous ones, attention was devoted not to political programmes, but to a search for competence in solving the social and economic problems of the city. The list of voters was revised, and the number rose to $1,369 .{ }^{35}$ Accordingly, the number of statutory members of the Duma rose to 80 . The elections were held in October 1913, and the Poles once again secured an absolute majority of seats. Węsławski became the head of the city for the third time. According to professions, the composition of the Duma comprised 16 officials from private institutions, 13 engineers, eight lawyers, seven physicians, six educators, six merchants, four functionaries, one dentist, pharmacist, industrialist and craftsman, and eight pensioners. ${ }^{36}$ The first meeting of the Duma and the elections to

32 P. Dąbrowski, Siła w kulturze, jedność w narodzie. Wileńska działalność społeczno-polityczna Michała, Witolda i Emilii Westawskich końcu XIX wieku $i$ pierwszej połowie XX stulecia (do 1930 roku) (Gdańsk, 2011), p. 64.

33 Wałdoch, 'Wybory do Rady miejskiej', p. 262.

${ }^{34}$ Ibid., p. 269.

35 Ibid., p. 271.

${ }^{36}$ Ibid., p. 273. 
the Board took place only on 8 January 1914, when the candidacy of the eight appointed Jewish representatives became clear, and the formation of the composition of the Duma was completed. ${ }^{37}$ The composition of the city's 1915 six-man Board comprised Michat Dobrowolski, K. Zubowicz, Jan Jabloński and Andrzej Tupalski, led by the same Węsławski and his deputy Konrad Niedziałkowski. ${ }^{38}$ This was the composition of the city government that encountered the German occupation in September 1915.

At the moment of the Russian withdrawal, the magistrate issued a proclamation to the population, in which it announced that in connection with the end of the activities of the civil authorities, the city's Board was taking care of the city, seeking to ensure order, security and peace. ${ }^{39}$ It also declared the belief that only disciplined behaviour by the population would be able to protect the city from possible threats.

\section{The administration of Vilnius during the first days of the German occupation}

The rule of Colonel Pfeil in the city was memorable, but very short-lived. His soldiers, on the very same day, moved from the city to the east after the retreating Russians. ${ }^{40}$ The main structures of the German 10th Army, led by General Hermann von Eichhorn, moved into Vilnius. The first governor of the city, General Adalbert Wegner, ${ }^{41}$ appeared in the evening of 19 September, and began to create his institution in the premises of the former Russian district court. ${ }^{42}$ Regulations in the German, Polish, Lithuanian and Jewish languages immediately appeared on corners of the city's streets, signed in his name, governing various matters of life under wartime

37 Ibid.

38 Pamiatnaya kniszka Vilenskoi gubernii na $1915 \operatorname{god}$ (Vilno, 1914), p. 27; for the personnel composition of the city's Duma at that time see: ibid., pp. 26-27; for details about the personnel composition of the Board in 1915 see: Dąbrowski, Siła $w$ kulturze, p. 72.

39 'Odezwa', Maty Kurier, 5(18) IX 1915, no. 26, p. 1.

${ }^{40}$ Von der Gebelentz, 'Die „Gespenster“ in Wilna', p. 1. The staff of Colonel T. Pfeil moved out of the St George Hotel on 21 September, having declared that all the expenses of their stay would be paid by the city's magistrate (Jankowski, $Z$ dnia, p. 256).

${ }^{41}$ Adalbert Wegner (1848-1916), German general, a Mason. For a brief time he was the commandant of the Kaunas fortress after its capture in 1915.

42 'Das Gouvernement Wilna', p. 2. 
conditions. Lieutenant-Colonel von Stolzenberg was appointed as the governor's chief of staff, ${ }^{43}$ who usually represented the governor in relations with the local population. In addition, Colonel Scharwächter became the city commandant (Ortskommendant), whom von Treskow replaced a few days later. ${ }^{44}$

Meanwhile, the city police continued fulfilling its duties, which did not decrease, but grew larger. As was predicted, while the city was still under Russian rule, the organising committee of the Citizens' Guard became the highest leadership of the city's police: F. Zawadzki became its head (the city commandant), and the other members of the organising committee became his deputies. ${ }^{45}$ The nine commissioners of the city's police departments were subordinate to this authority. Each department chief had two assistants. Each department was divided into two small ones, managed by junior departmental chiefs, in turn having one assistant. The police sergeants and the rank-and-file policemen directly under them formed the lowest structural link in the small departments. ${ }^{46}$ The ordinary policeman was required to wear a white armband on his left arm as a distinctive mark; senior members of the police, beginning from the sergeants, had a number of other distinctive signs. Ordinary policemen and sergeants had the right to use their insignia only while performing their duties. ${ }^{47}$ A principle of accountability from the bottom to the top was introduced: the chief of the administrative chain had to report every day on the state of affairs to his immediate superior. ${ }^{48}$

The competency of the department-level militia chain was not limited to law enforcement concerns only. The assistants of the department chiefs had to ensure that property owners, managers and guardians fulfilled their duties; they had to ensure that streets and buildings in their allocated territory were clean; and that changes of residence were recorded in the precincts. They also had to take care of the lighting of streets and public places, the observation of sanitary and hygiene conditions, the situation of beggars and

43 Ibid.

44 Jankowski, $Z$ dnia, pp. 248, 280.

45 'Straż Obywatelska w roku 1915', p. 2.

46 The structure of the city police is most extensively described: M. B., 'Šis tas iš Vilniaus miesto milicijos istorijos', Kalendorius „Vilniaus Aidas" 1916 metams (Vilnius, 1915), pp. 82-83.

${ }^{47}$ Ibid., p. 83.

48 'Przepisy dla Straży Obywatelskiej’, Mały Kurier, 5(18) IX 1915, no. 26, p. 1. 
the poor in the city, and the collection of taxes and duties. ${ }^{49}$ So, certain public utilities, health and social functions were included in the competence of the city's militia. The departments had their own secretariats, whose members wore blue ribbons on a white strap. ${ }^{50}$

Nevertheless, one of the most relevant primary concerns of the militia after the entry of the Germans became ensuring the permeability and non-interference of traffic, which with the movement of the massed army was especially important. There were also immediately some very threatening situations. For example, a few days after the entry of the Germans, one of their soldiers was shot in a suburb by unknown persons. The German commandants began to threaten the city with a fine of half a million marks. However, due to the efforts of the city's militia, it was proven to the Germans convincingly that the soldier had been shot outside the borders of the city, so they withdrew their claims. ${ }^{51}$ Altogether, it gradually became evident that the Germans regarded the militiamen without proper evaluation and respect, just as staff serving them. There was an attempt to impose on the militiamen functions that did not belong to them, and even to discredit their work. For example, they were ordered to gather, at night, quickly, from the city population the number of carters and wagons with horses that the army needed. Accompanied by armed soldiers, the militiamen had to wake sled owners at night and order them to prepare for the road. ${ }^{52}$ Otherwise, the Germans wanted to oblige the policemen to repair a hospital for their needs. ${ }^{53}$ Taking into account the specific and difficult conditions, a bureau was established at the highest city authority of the militia (the commandant of F. Zawadzki) to analyse the complaints of the population with respect to the Germans, as well as a bureau to fulfil the commands of the Germans. A third bureau oversaw the investigation of criminal affairs. ${ }^{54}$ The city militia consistently delegated two or three translators to the military commandant of the Germans, who had to refer the complaints of residents to the occupying administration. According to Zawadzki, both he and the

${ }^{49}$ Ibid.

${ }^{50}$ M.B., 'Šis tas iš Vilniaus miesto milicijos istorijos', p. 83.

51 'Straż Obywatelska w roku 1915', p. 2; Szklennik, Dziennik, LCVIA, f. 1135 , ap. 4 , b. $31,1.74$.

52 Szklennik, Dziennik, 1. 79.

${ }^{53}$ Ibid.

54 'Straż Obywatelska w roku 1915', p. 2. 
head of the city Węsławski every day at about 8 am had to rush to the governor's Chief of Staff, von Stolzenberg, to report on the situation in the city and listen to his complaints. ${ }^{55}$ The German requirements almost always exceeded their fulfilment capabilities.

The German structures in the city kept increasing. On 22 September, the chief burgomaster (Oberbürgermeister) Eldor Pohl ${ }^{56}$ and yet another German mayor (Bürgermeister) took office. ${ }^{57}$ Their appointment was motivated by the need to adapt the city's economy to the orders of the German administration, to wartime operations. The Oberbürgermeister wanted to have by him a Polish official, and he himself even declared his intention to learn Polish. Pohl was moved here from Tilsit, where before then he had served for a long time in the position of the head of the city, and became known for his courage and devotion to the interests of the city at the very beginning of the war, when some Russian soldiers had invaded Tilsit. ${ }^{58}$ In Vilnius, after his arrival, the rumour spread that the whole structure of the magistrate would be dissolved, and the city would be administered by a triumvirate, consisting of the German, M. Węsławski and K. Niedziałkowski. ${ }^{59}$ But the German plans were somewhat different, for the time being they did not rush to take over the management of the city by themselves.

At first, Pohl invited to his office representatives of all charitable societies, from whom he collected news about their activities, about suspicious people, and resources. ${ }^{60}$ In particular, he inquired about resources, stocks, for how long there would be sufficient funds for the needs of society. He promised to refrain from requisitioning warehouses of society if they did not contain products for more than two months according to the number of persons. ${ }^{61}$ The Germans, of course, specifically targeted the most sensitive and potent aspect of the city's life, national, and in part also confessional relations. The

55 Ibid.

${ }^{56}$ Eldor Pohl (1857-1935), German public figure, lawyer, originally from East Prussia. He was the mayor of Tilsit from 1900, became very popular, and in 1912 he was elected for a second 12-year term. In 1918 he returned to this office from Vilnius, he retired in 1924.

57 Häpke, Die deutsche Verwaltung, p. 23; Szklennik, Dziennik, LCVIA, f. 1135 , ap. 4 , b. $31,1.74$.

\footnotetext{
58 Jankowski, $Z$ dnia, p. 333.

${ }^{59}$ Ibid., p. 267.

${ }^{60}$ Klimas, Dienoraštis, p. 39.

${ }^{61}$ Ibid.
} 
organisations for the relief of war victims were organised on national grounds still under the conditions of the Russian government; they competed with each other. Overall, the war actualised and sharpened national relations, differentiating society on this basis. From the very beginning of the war, it was clear that even if it desired very much, under the new circumstances the Vilnius magistrate would not be an institution consolidating and representing the community of the whole city, and codifying its representative body, simply because of its disproportional Polish composition. In addition, due to the features mentioned above of its formation on the basis of property, the magistrate did not represent even the full social spectrum of the Polish part of the community. Therefore, long before the arrival of the Germans, movement began in the community of the city for the formation of an institution of the population on other grounds that could also function effectively under the conditions of the occupation. We should return once again and look at how this movement took place, and what consequences of it the Germans found.

\section{Initiatives for the Citizens' Committees}

On 23 October 1914, in the apartment of the Vilnius deputy burgomaster Niedziałkowski, activists of different Polish political factions founded the Polish Committee for Supporting War Victims. ${ }^{62}$ In the summer of 1915, in the circles of the landed intelligentsia, rallying around the Vilnius Land Bank, on the initiative of Stanisław Kognowicki and Bronisław Krzyzanowski, the idea was born to set up the Vilnius-Kaunas Citizens' Committee (Komitet Obywatelski Wileńsko-Kowieński), registered officially as a section of the relief committee (board) mentioned. ${ }^{63}$ According to the idea of the founders, the Citizens' Committee had to establish the damage caused by the military action, and settle issues of its reimbursement; citizens' organisations were needed in the provinces of Vilnius and Kaunas, which would address the local needs of the population; they had to take care of the organisation of the cultivation of land; and they had

${ }^{62}$ P. Dąbrowski, Narodowa Demokracja byłego Wielkiego Księstwa Litewskiego. Studium z zakresu myśli politycznej i działalności obozu narodowego na ziemiach litewsko-biatoruskich w latach 1897-1918 (Cracow, 2010), p. 51.

${ }^{63}$ Ibid. For more details about the origin and intentions of the Citizens' Committee see: Lopata, 'Lietuvos valstybingumo raida', pp. 51-54. 
to ensure the care of refugees or organise their return. ${ }^{64}$ Landlords from the province of Kaunas who were in Vilnius on matters of the Citizens' Committee, such as Montwila, Świątecki and Kosska, initially sought to consult with Węsławski, the head of the city, but he did not agree, because the individuals mentioned had 'unclear' political views. ${ }^{65}$ But the landlords not belonging to the National Democrats (nationalists) did not abandon their ideas. ${ }^{66}$ The modernising spirit of the time, the entry of the lower layers into the social and political arenas, forced some Lithuanian landlords to change their conservative views (some were gradually approaching the provisions of the krajowcy), or at least to conceal them with modern slogans. Understanding that the national movements were running high and could simply sweep them away, certain representatives of the landlords quite sincerely tolerated the national movements of the region, and sought points in common with them in order to connect with them and direct them in a suitable direction. Since, like before, among the landlords opinions in favour of union with Poland dominated, this direction was quite clear. ${ }^{67}$ In July, Aleksander Meysztowicz appealed in their name to the Russian government, asking to establish a committee. Officially, it was explained to the government that the Citizens' Committee would care for the affairs of the population of the city of Vilnius, and the provinces of Vilnius and Kaunas, and would represent them. Unofficially, emphasising the principle not of ethnic exclusivity, but of civic trust, the initiators of the Citizens' Committee urged the politicians not only of the Poles, but also of the Lithuanians, Belarusians and Jews, to work together. It was a far-reaching idea, with circumstances developing favourably to turn the committee being formed into an embryo for the future

${ }^{64}$ Dąbrowski, Narodowa Demokracja, p. 54.

${ }^{65}$ Jankowski, Z dnia, p. 160.

66 Before the coming of the Germans, the National Democrats proposed establishing a Polish committee that would try to take over at least part of the authority from the retreating Russian government and become the representative of the region against the Germans. This was based on the assumption that the Germans would reckon with 'historical' nations, which the Poles were. But later, for a while, the National Democrats abandoned this idea, being one of the reasons that also the Vilnius magistrate opposed it. For more information see: J. Jurkiewicz, Rozwój polskiej myśli politycznej na Litwie i w Białorusi latach 1905-1922 (Poznań, 1983), pp. 120-121.

${ }^{67}$ Lopata, 'Lietuvos valstybingumo raida', pp. 52-53. 
of the government of the Grand Duchy of Lithuania. ${ }^{68}$ The Russian government did not have a unified approach to such a committee. Since the duties of interior minister went to the hard-line Nikolai Maklakov, permission was not given. As soon as the liberal Nikolai Shcherbatov replaced him at the beginning of August, permission was issued on 2/15 September. ${ }^{69}$ On the day before the entry of the Germans into Vilnius, the departing governor Pyotr Veriovkin approved the statutes of the Citizens' Committee, and essentially transferred the functions of the Russian administration to it (except for Vilnius itself, where the magistrate operated). ${ }^{70}$

At the same time, another very similar initiative was born and developed, in which the talk revolved only around the affairs of the city. On 11/24 August, on the initiative of the Polish engineer Julian Januszewski, a meeting was organised of representatives of the city's nationalities, to which, in addition to the three representatives of the Poles, were also invited three representatives of the Lithuanians, Belarusians and Jews. ${ }^{71}$ True, this number did not turn up: the Jews delegated Jakov Vygodskij and Simon Rosenbaum, the leaders of their Committee for Supporting Victims of the War, from the Lithuanians came only Jonas Vileišis, and from the Belarusians Anton Łuckiewicz. Januszewski, Aleksander Szklennik and Gabriel Sokołowski represented the Poles. The aim of the meeting was to decide on the formation of the Vilnius city Citizens' Committee. ${ }^{72}$ Unlike the planned Citizens' Committee discussed at the level of the landlords in two provinces, in this case a very similar initiative by the Committee raised the figures of separate national groups of democratic views representing more the lower strata of society. ${ }^{73} \mathrm{At}$ the beginning of the meeting, a consensus was reached that represen-

${ }^{68}$ Jundziłł, 'Z dziejów', pp. 62-65.

${ }^{69}$ Lopata, 'Lietuvos valstybingumo raida', p. 54.

${ }^{70}$ Ibid.; A. Pukszto, 'Postawy wileńskich Polaków pod niemiecką okupacją w latach 1915-1918', Ostatni obywatele Wielkiego Księstwa Litewskiego, eds. T. Bujnicki, K. Stępnik (Lublin, 2005), p. 281.

${ }^{71}$ Szklennik, Dziennik, LCVIA, f. 1135, ap. 4, b. 31, 1. 14-15.

72 Ibid.

73 The Polish historians P. Dąbrowski and A. Pukszto are obviously mistaken in shaking up these two initiatives into one (Dabrowski, Narodowa Demokracja, pp. 51-52; idem, Siła w kulturze, pp. 52-53; A. Pukszto, 'Wilno pod koniec 1915 r. - na początku 1916. Polskie czy niepolskie?', Przeglad Wschodni, vol. 8, z. 1 (2002), p. 45). Szklennik, whose diary Dabrowski also used, very clearly distinguishes them. C. Jankowski also clearly distinguishes the initiatives (Jankowski, $Z$ dnia, p. 160). 
tation in the planned institution should be equal for each nationality; proportional representation was not possible, because the true number of Lithuanians and Belarusians in the city was unknown. ${ }^{74}$ At the same time, the Poles admitted that the Lithuanians in the city were the real autochthons, and that the Belarusians actually represented a significant segment of the population, because, for example, nearly all the city sewerage system's workers were Belarusians. Difficulties arose when the discussions began on the principle of the delegation of representatives to the intended committee. All wanted the public organisations of the nationalities to put forward candidates, but it turned out that, for example, the Jews had about 200 different organisations, while the number of Lithuanian and Belarusian organisations was quite modest. ${ }^{75}$ The participants agreed that the best solution would be broad democratic elections, but they also admitted that, under the existing difficult circumstances, they were not possible. The decision made was that in the current situation, nevertheless, they should rely on the existing city government, first making its composition significantly more democratic. ${ }^{76}$

The direct pretext was that due to the conditional migrations and evacuations of the war, the city's Duma in August 1915 was already in meltdown: there were only about 40 of its members in the city. ${ }^{77}$ Most representatives simply decided to propose that the Duma should be supplemented by representatives of the nationalities. Minutes of the meeting were drawn up, to be handed over to the existing Duma representatives. They stated that it was proposed to supplement the Duma with a minimum of 30 representatives of the nationalities, with half of the seats assigned to Jews, and the rest (five each) distributed equally to Poles, Lithuanians and Belarusians. The proviso was also included that places would be allocated to those segments of society that were not represented up to now in the city's Duma. ${ }^{78}$ It is interesting that the Polish figure Czesław Jankowski, who was not directly connected with this action, predicted in his diary on 15/28 August a nine out of ten chance that the magistrate would not agree with this idea. The city's Duma, in general, considered the institution of the Citizens'

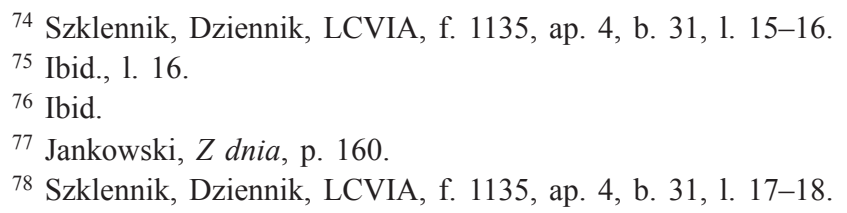


Committee unnecessary, because it still had the same powers and responsibilities, and still felt capable of carrying them out alone. ${ }^{79}$ Events turned out more or less according to this forecast. After submitting the initiative to the Duma, Januszewski immediately attracted sceptical questions from its members, such as why 30 new members were proposed instead of 40 or 50 ; whether there was any guarantee that other similar proposals would not come; and specifically which layers of Poles were not represented in the Duma, and the like. ${ }^{80}$ Nevertheless, the Duma promised to consider the initiative, and to set up a commission for it. This was done, the commission proposed that the nationalities present a list twice as long of 60 people, from which the Duma itself would choose the representatives to work in the permanent commissions existing from before, but not in the Duma plenary meetings with the right to vote. ${ }^{81}$ The nationalities did not agree to this, and tense negotiations continued almost until the arrival of the Germans. On 27 August (9 September) an agreement was reached in principle, according to which ten Jews, four Lithuanians, two Belarusians and two Poles could become members of the city's Duma, but after going on to a discussion of specific candidates, disputes again continued. ${ }^{82}$ After the Germans came, the issue became even more complicated. On 1 October the representatives of the nationalities stated that the issue was stuck, the magistrate was not accepting any dialogue about it, and threatened in writing that he would not hold himself accountable in any way to the Duma for it. At the same time, however, he admitted that the position of the magistrate was difficult, and under the conditions of the German administration no official meeting of the Duma took place. ${ }^{83}$

We should note here that the Duma's position on the admission of representatives of the nationalities determined not only the alleged or real arrogance, and the unwillingness to share power, but also the fear of the return of the Russians. The members of the Duma bluntly lectured the representatives of the nationalities on this in the negotiations. According to them, international and military law respected the existing legislation in the occupied territory, so

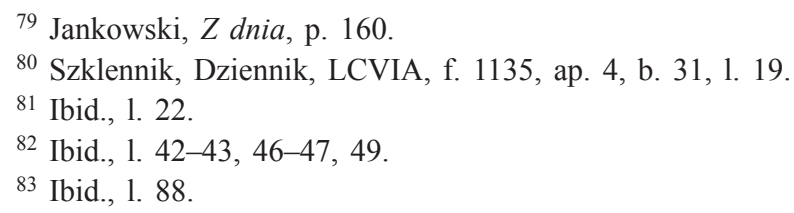


those who were coopted after the German occupation would not have equal rights with former members of the Duma, because they would not be elected in accordance with those acts; together with arbitrary actions in this context, the returned previous government would be able completely realistically to hold to account the persons responsible. ${ }^{84}$ The initiators of supplementing the Duma repulsed these fears, indicating the situation evolving in Congress Poland. Led by a few Germans, the old city councils there continued their work, supplemented by several dozen new representatives delegated by the communities of these cities, and thanks to this no particular problems arose. The Citizens' Committees were also a routine matter. Moreover, the Vilnius Duma was already told that it was in breach of the 1892 Russian law when it recognised the organization of the city's militia. ${ }^{85}$ In the end, a compromise was reached: after the Germans entered, the Duma ended its official activities, and only informal meetings took place, in which the coopted representatives of the nationalities with the right to vote also participated, and in the event of the return of the Russians, they would withdraw from its composition. ${ }^{86}$ Nevertheles, the fear of the Duma had some foundation: it showed that contemporaries also applied the warning of the departing Governor Veriovkin to the members of the magistrate: 'Remember, Gentlemen, you remain here, but we will return! And when we return, the interrogation will investigate very rigorously every detail of your position with regard to the Germans... ${ }^{97}$

The annoyance expressed on 1 October by the representatives of the nationalities was actually caused by the fact that they were not invited to an informal meeting of the city's Duma, and, according to the news, at least a few had taken place since the arrival of the Germans. It is natural that in such circumstances the attention of the representatives of the nationalities turned increasingly to the Vilnius-Kaunas Citizens' Committee, because its prospects looked more and more promising. For the Vilnius players of democratic views, the rapid transformation of this committee in what they perceived as a positive direction seemed the most seductive. The very open, public principle of the formation of the committee already attracted the attention of the public. The initiators invited to the

\footnotetext{
${ }^{84}$ Ibid., 1. 21-22.

${ }^{85}$ Ibid., 1. 22-23.

${ }^{86}$ Ibid., 1. 28.

87 Jankowski, Z dnia, p. 180.
} 
organisational meeting on 22 August (4 September) up to 80, in their opinion, well-known and influential public figures in Vilnius, of whom 65 arrived. ${ }^{88}$ Among them were also the mentioned initiators of the expansion of the city's Duma. One of the latter, A. Szklennik, wrote in his diary that it was quite unusual that the meeting did not discuss at all the programme and goals of the committee. Stanisław Kognowicki presiding, after presenting the history of the origins of the committee, outlined only the common organisational vision: to organise, focus, and then expand the framework of activities attracting other nationalities and social strata in the region. ${ }^{89}$ The work of the meeting concentrated on the task of forming the committee; for a start, it aimed in a few stages to elect eight persons, who would then co-opt four more. In the first stage of the elections, all the participants in the meeting could participate. ${ }^{90}$

So, in a few days, the first 12 members of the committee, all Poles, became known. ${ }^{91}$ According to the original vision, they were to become the core of the Committee. Even the Poles themselves were sceptical about it: C. Jankowski considered it just another manifestation of National Democrat activities; ${ }^{92}$ about the committee, it was said that it 'elected itself'. ${ }^{93}$ At this stage in its formation, quite unexpectedly, even for its very own members, the committee was also approved by the withdrawing Russian authorities. The next stage of its activities began: to attract other nationalities and layers. Lithuanian, Belarusian and Jewish politicians looked at this initiative quite carefully. However, after it became clear that the krajowcy agreed to the formation of the Citizens' Committee and to delegate representatives to it, the krajowcy included Conservative landlords and Polish socialists, and only a few places went to the supporters of the National Democrats (ND), from the beginning, the Belarusians, and then the Jews, agreed to participate in it. ${ }^{94}$ The Lithuanians were divided on this issue: Democratic Party (LDP)

${ }^{88}$ Szklennik, Dziennik, LCVIA, f. 1135, ap. 4, b. 31, 1. 37.

${ }^{89}$ Ibid., 1. 37-38.

${ }^{90}$ Ibid., 1. 38.

${ }^{91}$ Jankowski, $Z$ dnia, p. 200; Jundziłł, 'Z dziejów', p. 71. For more information about the composition of the Citizens' Committee according to different sources see: Jurkiewicz, Rozwój polskiej myśli, pp. 120-121.

92 Jankowski, $Z$ dnia, p. 200.

${ }^{93}$ Szklennik, Dziennik, LCVIA, f. 1135, ap. 4, b. 31, 1. 90.

${ }^{94}$ Klimas, Dienoraštis, p. 28; Lopata, 'Lietuvos valstybingumo raida', p. 53. 
members were inclined to contribute, also urging others to follow their example, while the Conservatives (Nationalists and Christian Democrats) and the Social Democrats had serious doubts. In their view, the principle of the formation of the Citizens' Committee did not comply with the national composition of the population, only two gubernias were identified, and so on. The Democrats agreed, but vowed to rally an opposition in the committee to control the work of the Poles. ${ }^{95}$ The authority of the Committee, in the eyes of the Lithuanians (and other nationalities), was increased by its reaction to the famous proclamation of Pfeil. In reacting, the Committee sent a delegation to the colonel, which stressed that Vilnius was the capital not of Poland, but of the GDL. ${ }^{96}$ Afterwards, on 23 September, the assembled Lithuanian figures decided to delegate to the Citizens' Committee the Democrats J. Vileišis, Jurgis Šaulys, Vladas Stašinskas and B. Žilinskas, the Nationalist Jonas Kymantas, and the Social Democrat Pranas Eidukevičius, and to see what came out of it. ${ }^{97}$ Although some adjustments were still made in the national and personal composition of the Committee, 24 to 26 people finally formed its structure; Vileišis became one of two vice-chairmen of S. Kognowicki, and Stašinskas one of the two secretaries of the Committee. ${ }^{98}$

The Citizens' Committee was tolerated from the beginning by the arriving Germans, and it was even given a vote in an advisory capacity discussing matters related to the provinces of Vilnius and Kaunas. ${ }^{99}$ By the last days of September, the Germans had started to transform the Vilnius militia, significantly reducing its numbers, and making the places paid. The public immediately raised doubts about whether it was possible to occupy places in the emerging German administration and accept paid salaries. The fear of the return of the Russians affected not only members of the magistrate. How deeply this factor had penetrated the public consciousness showed: even after the arrival of the Germans, the Vilnius clergy, according to an old order, still remembered the Russian tsar in their prayers. ${ }^{100}$

95 'Piliečių komitetas', Kalendorius ,, Vilniaus Aidas “ 1916 metams, pp. 84-85; Klimas, Dienoraštis, p. 28.

96 Lopata, 'Lietuvos valstybingumo raida', p. 54.

97 Ibid.

98 Dąbrowski, Narodowa Demokracja, p. 54.

99 Jankowski, Z dnia, p. 278.

100 Ibid., p. 276. 
The opinion of the Citizens' Committee was asked on the question of German service and wages. After a heated debate, it decided by a majority that services and salaries could be accepted only in the case of a clear German order. ${ }^{101}$ Thus, on 4 October the news that spread in the city that the Germans had officially acknowledged the Citizens' Committee was again a little unexpected, not only for the public, but also for its members. ${ }^{102}$

\section{The German administration in Vilnius in the autumn of 1915: strengthening its position and flirting with the Poles}

On the subject of the intentions of the Germans in addition to recognising the magistrate and the Citizens' Committee, it seems that we should first talk about their aspiration to secure the role of the determinant arbitrator: after all, the competencies of the two institutions were still uncertain and intertwined, so it was obvious that sooner or later, in the event of a conflict of interest, the final word would inevitably be with the military administration; moreover, the situation provided an opportunity to keep both institutions 'on a short leash'. Also, we should bear in mind that they were far from the only objects of the application of German policy. We have already mentioned the quite independent role that the city's militia played, as well as the charitable organisations that ended up under the attention of the newly appointed Oberbürgermeister. In the last days of September, a council was established at the German headquarters to discuss general matters; it was composed only of the leadership of the city's militia, and the chairman of the Citizens' Committee, so it was exclusively Polish; other nationalities immediately noticed that their interests were hurt by this. ${ }^{103}$ It would be sufficient to add just a whole set of other former or newly founded institutions and organisations on national grounds in Vilnius to reveal the truly infinitely wide scope for the application of the occupations policy of 'divide and rule'. But here we will limit ourselves only to the administrative institutions.

The position of Oberbürgermeister Pohl and his German deputy at that time almost imperceptibly but continuously strengthened. For example, the deputation from the Lithuanian Committee, ha-

101 Ibid., p. 278.

102 Ibid., pp. 292-293; Szklennik, Dziennik, LCVIA, f. 1135, ap. 4, b. 31, 1. 90.

103 Klimas, Dienoraštis, p. 37. 
ving travelled to the governor, was not accepted, but was sent to the Oberbürgermeister. ${ }^{104}$ Pohl could also express himself more strongly because he had received the direct support of the power structure: in early October, the German Polizeimeister V. Wasielewski came to the city with a number of qualified police officers. ${ }^{105}$ Soon, in addition to the city's militia, they began to patrol the streets of Vilnius. The already-mentioned planned reorganisation of the city's militia was associated with it. Meanwhile, the positions of the old magistrate and its leader Węsławski still declined, as the Germans heeded his voice less and less. This was due not only to objective processes, but also to the personal characteristics of the head of the city, such as lack of principles, shortage of initiative, and finally old age. In the opinion of many, Węsławski was the 'wrong man in the wrong place'. ${ }^{106}$ The Germans described him as a typical 'statssovetnik'. 107 The fear of the return of the Russians, which conditioned actions and hindered adopting relevant decisions, further restrained him and the whole magistrate. Von Stolzenberg, the head of the governor's staff, did not avoid derogatory public comments about Węsławski, and in their talks he would shout. In society, the continuing record-keeping of the city's Board in the Russian language seemed a great anachronism, at a time when the teaching of the Russian language was banned, and all private Polish offices used the Polish language. The institutions, shelters, canteens and so on, at the disposal of the Board also had to use the Russian language in their record-keeping. The Poles themselves feared that the German administration would use that, and at some time, without great scruples, replace the Russian government language with another government one, German. ${ }^{108}$ Meanwhile, the earlier cherished hopes of the city's public with regard to the city's Duma appeared entirely unjustified: the Germans simply did not miss such an institution at all and did not legitimise it.

In October 1915 the other aspirations of the German administration associated with the Citizens' Committee also gradually began to emerge. The committee prepared and on 19 October handed to

104 Ibid., p. 39.

105 Jankowski, Z dnia, p. 278; Szklennik, Dziennik, LCVIA, f. 1135, ap. 4, b. $31,1.93,118$.

106 Jankowski, Z dnia, pp. 333-334.

107 Szklennik, Dziennik, LCVIA, f. 1135, ap. 4, b. 31, 1. 131.

108 Ibid. 
von Stolzenberg the memo 'On the abnormal economic, and partly public relations determining the historic rupture involving the region and the lack of actual power', ${ }^{109}$ addressed to Paul Hindenburg, the commander-in-chief of the army. The wording showed the rather provocative nature of the memo. The Germans were asked to remedy the situation. But von Stolzenberg calmly took the letter and promised to deliver it to Hindenburg, and even declared that he was ready to support the 'rational' efforts of the Committee. At the same time, local activists also heard some other news: first, the request of the 10th Army commander General Eichhorn to meet with several local Polish 'obyvateli' and talk about city and state affairs in confidence. ${ }^{110}$ The second important item of news was that in the province of Kaunas and in the part of the Vilnius province west of Vilnius, gradually but without delay, a civil administration had to be introduced; it had to be created on a small scale, and its management given exclusively to Poles; the specific candidacies of noble Poles were also mentioned. ${ }^{111}$ Moreover, the posts would allegedly be assigned not by way of proposal, but simply on an order. Without doubt, this news flattered Polish amour-propre. In his diary, C. Jankowski wrote that the German government was slowly beginning to reckon with local 'influential spheres', first of all with the Citizens' Committee, and in it exclusively with Poles; from the point of view of the Germans, the Lithuanians for some reason, and the Jews for others, had to be Germanised, the Belarusians Polonised, and farther to the east Russianised. ${ }^{112}$

It is evident that at the beginning of the occupation of Vilnius and the surrounding region the shapers of the objectives of the local German leaders began to implement targeted policies that were to be simultaneously adapted to all the shifts in Germany's foreign policy. In September 1915, the question of Poland once again appeared at the centre of attention of the Reich's foreign policy strategists. At the same time the commander-in-chief of the German forces General Erich von Falkenhayn, a famous supporter of the 'Central Europe' concept, on 8 September suggested to the chancellor to exploit the factor of Poland as appropriately as possible for German inte-

\footnotetext{
109 Jankowski, $Z$ dnia, pp. 320-321.

110 Ibid., p. 321.

111 Ibid.

112 Ibid., pp. 319-321.
} 
rests. ${ }^{113}$ The Poles were seen first of all as a significant source for supplementing the 'live power' of the military forces, but for that they had to have policies that were attractive to the Polish public. At the top of the German government, a vigorous debate evolved covering all issues of Poland's statehood. The question was not easy, because from the very beginning of the war, Austria-Hungary was included in the decision: the Germans were inclined to transfer to its authority the lands of the Poles seized from Russia, but due to various circumstances and factors, there was no agreement about the effects, although it appeared that it was close at hand. This time, the epicentre of the discussions again moved back to the plane of German and Austrian relations. Gottlieb von Jagow, the foreign affairs minister, emphasised the importance of Poland in the struggle against Russian power, and the dangers of Panslavism. He considered that the best solution would be an autonomous Poland under the Habsburg monarchy, but at the same time also again raised reservations and doubts about the final realisation of this version. ${ }^{114}$ However, the fact that in the autumn of 1915 the Poles again felt that they found themselves in the centre of attention of Germany's policies was most important. The Poles of Vilnius were also no exception here. German officers and officials began to explain to them that a kingdom would be established on the basis of Congress Poland, ruled by the Saxon dynasty, into which would also be included the district of Bialystok, the lands between Grodno and Lida, and almost all of the Vilnius province; only before that, the Poles would have to unequivocally renounce the Poznan lands. ${ }^{115}$ This was not a new idea: the territorial expansion of Poland to the northeast (including Vilnius and Grodno) was discussed by the German government at the very beginning of the war in 1914. At the same time and in parallel, the idea of the connection of a re-established Poland to the Habsburg monarchy began to be discussed. ${ }^{116}$ Not receiving the enthusiasm of the Poles, and after the collapse of the concept of the 'lightning war', this idea then faded, but it was again revived as an outcome of the successful attack by the Germans in the summer of 1915 .

${ }^{113}$ F. Fischer, Griff nach der Weltmacht. Die Kriegszielpolitik des kaiserlichen Deutschlands 1914-1918 (Düsseldorf, 1961), p. 169.

114 Ibid., pp. 170-178.

115 Jankowski, $Z$ dnia, pp. 322-323.

116 Fischer, Griff nach der Weltmacht, pp. 102-103. 
In the late autumn of 1915, there was still no progress in the administration of the Vilnius region. On one hand, according to the statement by the representative of the cooperative movement A. Szklennik, there was absolutely no organisation in the province except for the parish; the new rulers, expanding from a military point of view, did not pay any attention at all to civil administration. ${ }^{117}$ At that time, the shortage of food and essential supplies was already being severely felt; therefore, the idea arose in Vilnius to create a diocesan-wide Procurement Committee, at the forefront of which would stand the administrator of the diocese, the Rev. Kazimierz Michalkiewicz. The organisational skeleton was already even formed, and authorisation from the Germans was being sought. ${ }^{118}$ On the other hand, according to the testimony of C. Jankowski, the improvised creation of the civilian administration was taking place at the same time; Jankowski submitted the example of the Širvintos district. The German commandant there confirmed eight districts (Bezirk), headed by governors (Bezirkvorsteher). They were territorial entities, about the size of two parishes, the heads of which, by order of the Germans, were local Polish landlords or managers of estates: the Sutkuškis landlord Jan Krukowski in Kernavè, the Maišiagala landlord Witold Houwald in Maišiagala, the Michališkiai landowner Stanisław Drucki-Podbereski in Musninkai, and so on. Only in Kiauklènai was a local pastor appointed head. ${ }^{119}$ This improvised management took place to the west of Vilnius, where the Germans announced the existence of a 'communications area' (Etappengebiet). Meanwhile, to the east of the city, up to the front line, as was previously announced in Polish to society, there existed an 'operations area' (Operationsgebiet), and it was planned to continue to maintain it, administered exclusively by German soldiers. ${ }^{120}$

By October 1915, initially very discreetly, in addition to all other German institutions, the alleged civilian administration headed by

117 Szklennik, Dziennik, LCVIA, f. 1135, ap. 4, b. 31, 1. 126. The Lithuanian actor Peliksas Bugailiškis in his own notes at that time also several times remarked that the Germans 'were in no hurry' to sort out Vilnius, and were delaying civilian rule (Klimas, Dienoraštis, pp. 32, 39).

118 Szklennik, Dziennik, 1. 124-126. However, on 7 December it turned out that the Germans were allowing the founding of only separate parish committees, but were not allowing a central committee of the diocese (ibid., b. 32, 1. 11).

119 Jankowski, $Z$ dnia, p. 366.

120 Ibid., p. 321. 
Rittmeister Rudolf von Beckerath ${ }^{121}$ began to be founded in Vilnius. Finally, on 23 November, his signed 'announcement' appeared, by which the public was informed that there existed a German Vilnius Board (Die Deutsche Verwaltung Wilna), which 'covers the area of the theatre of the 10th Army to the east of the Neman' and was under the 10th Stage ${ }^{122}$ inspection. The territory of the board consisted of the city of Vilnius, and the 'already being joined' districts of Vilnius, Kaišiadorys, Merkinė (with its centre in Alytus), Širvintos, Molètai and Pabradè. ${ }^{123}$ At the beginning, this did not bring any clarity to the existing situation; it was too difficult for local society to predict that this body would gradually become the most important. According to the perception that existed, the institution with the word gubernia in its name, therefore the office led by General A. Wegner, was still the most important. However, in his notice at the end of September, he had defined the boundaries of the administered territory: from Duseninkai along the River Voké until Verkiai, from there towards Nova Vileika, and again along the Nemeža until Duseninkai. So the gubernia of General A. Wegner and his chief of staff von Stolzenberg included only Vilnius itself. ${ }^{124}$ Wegner himself in his announcement on 21 September stressed clearly that he became the governor of Vilnius city. ${ }^{125}$ His institution was called in German Das Kaiserliche Gouvernement Wilna. For residents, meanwhile, it seemed that the gubernia, although it was German, could not be limited to the city itself. So when the institution of R. von Beckerath appeared, it was mistakenly called a gubernia, and its head 'the governor'. The Germans themselves appreciably contributed to this, because in documentation they began to mix up both names, using the expression 'Das Kaiserliche Gouvernement und die deutsche Verwaltung Wilna'. ${ }^{126}$ And this name was not accidental, since initially the two institutions essentially looked after

121 Ibid., p. 334; Szklennik, Dziennik, LCVIA, f. 1135, ap. 4, b. 31, 1. 126.

122 I.e. the rear of the 10th Army.

123 'Vilniaus Valdymo pranešimas apie jo ploto didumą 23.11.1915', Paliepimu lapas Ciesoriškajai Gubernijos Valdybai ir Vokiečiu Valdybai Vilniuje (Vilnius, 1915), no. 2, p. 31 (parallel text in the German and Polish languages).

${ }^{124}$ Klimas, Dienoraštis, p. 35; Jankowski, Z dnia, p. 334.

125 'Gubernijos Valdybos apskelbimas, paliečiantis Vilniaus miesto perejjimą i vokiečių valdžią, 21. 9. 1915', Paliepimu lapas..., no. 1, p. 9 (parallel text in the German and Polish languages).

${ }^{126}$ In this way, e.g., it is done in the German title of the above-mentioned 'Sheet of orders'. 
the same matters, only according to the idea of the higher authority, the institution of A. Wegner gradually had to transfer all the affairs of the civilian population to the competence of the Board of von Beckerath. ${ }^{127}$ In addition, it appears that the German government did not even try to introduce clarity, because in a political sense it was convenient just to play with the concept of gubernia, i.e. to uphold among the population the territorial perception of the former gubernia, although very reduced. ${ }^{128}$

Jankowski mentions in more than one place in his notes that so many institutions of government were gradually created in Vilnius that it became completely unclear who was responsible for what. Among the Germans in the city, the highest according to rank was the commander of the 10th Army, H. von Eichhorn, staying in the Tiškevičius palace by the River Neris. On 24 October he invited to a party in his residence not only all the heads of the German administrative bodies, but also those of the local representations (city magistrate, Citizens' Committee, even the Vilnius Diocese). ${ }^{129}$ This was done for the purposes of better knowing each other, and finding common ground; the gathering did not tackle any practical issues, so with regard to the distribution of competencies, the existing totally unclear situation continued. A sort of Gordian knot had resulted, to unravel which the jus gladii ('right of the sword'), according to Jankowski, belonged to Field Marshal P. Hindenburg himself and his headquarters, but from there no efforts were seen... ${ }^{130}$

\section{A turn in the German policy of administrating: the inclusion of Vilnius in the Oberost system}

At that moment, the local society of Vilnius and the whole occupied region did not know which plans of the Germans with respect to the region had begun to be carried out. Everyone had heard about various versions of the decisions of the Germans, almost all of

${ }^{127}$ Rudolf von Beckerath (1863-1945), German lawyer and government official. Since 1897 he carried out the Landrat duties in Alten, Dillkreis and Hanau. He was the chief of the Hanover Police from 1909 until his appointment to Vilnius in 1915. He returned from Vilnius to the same duties, which he continued up to 1928.

${ }^{128}$ It is interesting that the German authorities were not institutions of the German province in Kaunas and Suwalki, while such a one in addition to Vilnius also existed in Grodno.

129 Jankowski, $Z$ dnia, pp. 331-333.

130 Ibid., p. 334. 
which in one way or another were tied to Poland and its future. The Poles of Vilnius constantly glanced at the situation in Congress Poland, and waited for when the Germans here would pursue a similar policy, particularly associated with the creation of the civil administration. But Hindenburg's jus gladii began to operate in the opposite direction. At the end of October 1915, Hindenburg's chief of staff General Erich Ludendorff, who set out after a break of many centuries to renew the 'cultural action' of the Teutonic Order in the East, first of all began to reorganise and centralise the occupying administration in Kaunas. ${ }^{131}$ From 4 November the special 'administrative departments' (divisions), performing the role of the occupied territory's central government in the east began to function in the headquarters (to which, incidentally, General von Eichhorn's 10th Army was also directly subordinate). In the next step, in secret circulars to the local administrations, Ludendorff demanded insistently an end to the policies of protecting the Poles. ${ }^{132}$ That was quite easy to carry out in the western part of Lithuania, in Žemaitija, but too difficult in Vilnius. So, for a while, events evolved from inertia along the old pro-Polish furrow. Finally, Ludendorff himself was not a very clear authority for the local administrators at the beginning. However, in mid-November, the first serious sign of the changing policies towards the Citizens' Committee was felt. The Lithuanian activists felt cheated and discriminated against by the Poles through the Citizens' Committee, in dividing funds from abroad for charity for Vilnius society. ${ }^{133}$ The desire of the Poles not to share the funds with other nationalities became known through von Beckerath's office. This accentuated anew the national tensions in Vilnius, and eroded the foundations of the existence of the Citizens' Committee. The Lithuanian Nationalist J. Kymantas immediately announced that he was withdrawing from it. Overall, the Lithuanian right watched with anxiety until then the flirting between Polish figures and the German administration, and in respect to the Citizens' Committee, they were very reticent and reserved. Now they had found an overwhelming

${ }^{131}$ W. Sukiennicki, 'Początki Ober-Ostu i sprawa Konfederacji W. Ks. Litewskiego w 1915-1916’, Zeszyty Historyczne, 28 (1974), pp. 100-101.

132 Ibid., p. 101.

133 About the history of the allocation of the funds most comprehensively see: Jundziłł, 'Z dziejów', pp. 68-69; as well as Klimas, Dienoraštis, pp. 56, 58; 'Piliečiu Komitetas', pp. 85-86. Although the details of the individual stories vary, the essence remains the same. 
argument to feel righteous, and hoped for the favour and support of the Germans. The decision of the latter, signed by Hindenburg himself, was such that the activities of the Citizens' Committee were limited only to Vilnius, and only for the care of refugees. ${ }^{134}$ This meant completely undermining the importance of the Committee. Von Beckerath's administration itself took over the distribution of charitable funds received from abroad to Vilnius nationalities, and ensured it was done through the separate charitable committees the nationalities had. ${ }^{135}$ In connection with this, the Polish Democratic activist Z. Jundziłł regretted that, due to national interests (he blamed the Poles in particular), a very important institution for the future of the region had been dismantled by their own hands and they were yielding to German directives. ${ }^{136}$

The members of the Citizens' Committee, having received this blow from the Germans, at the beginning thought of liquidating totally the whole institution; but later, nevertheless, they decided to try to continue its very constrained activities. Further away, more in Vilnius, shortages of food products and goods were felt, and serious disagreements and tensions arose in the process of supply and sales. Affairs of subsistence and survival pushed aside all other matters. This sphere, as earlier also, was still theoretically in the competence of the city's Board, but actually from the outbreak of the war the situation had changed beyond recognition; actual strands of activities rallied in the hands of the active part of society, directly dependent on its initiatives. The significance of committees for the relief of war victims founded on a national basis was growing, and other local public organisations tried to keep up with them. The cooperatives and workers' trade unions kept demanding that the magistrate include their representatives in decisions about the supply of the population's affairs. ${ }^{137}$ The centre of attention this time focused on the functions of the Supply Commission of the city's Board, although in general the talk still revolved around the same already-discussed issue of the democratisation and reform of the magistrate. Against the background of the city's shortages, a certain, although only temporary but quite real, compromise became evident: the Board

134 Jankowski, Z dnia, p. 381; Szklennik, Dziennik, LCVIA, f. 1135, ap. 4, b. $31,1.132-133$.

135 Sukiennicki, 'Początki Ober-Ostu', p. 100; Klimas, Dienoraštis, p. 71.

136 Jundziłł, ‘Z dziejów’, p. 69.

${ }^{137}$ Szklennik, Dziennik, LCVIA, f. 1135, ap. 4, b. 31, 1. 133. 
allowed representatives of the city's society not into the activities of the very magistrate, but into its Procurement Commission. The half-dead Citizens' Committee also saw an opportunity to intervene: the Board proposed to the Committee to invite representatives of eight social organisations to a meeting, and organise the election of delegates from among them, to whom would be granted the rights of experts in the Procurement Commission. ${ }^{138}$ At the end of November 1915, this was carried out; among others, representatives of national Polish, Lithuanian, Belarusian and Jewish relief committees became members of the Procurement Commission. ${ }^{139}$ Thus, in the context of difficulties, a certain partial practical solution consolidating the city's society was finally achieved.

The trend in the convergence of the city's magistrate and the Citizens' Committee also continued later. For example, on 26 January 1916, a meeting of the city's intellectuals was called at the initiative of the Citizens' Committee on the issue of taking out a loan for the city. The issue of the city's debt to the Germans, who supplied food products and covered certain financial costs, became more and more acute. Since this first of all affected the lower social strata, the working classes, representatives of the workers drew up a memo with a plan to cover the debt, which it presented for debate by the whole city community. At the meeting, members of the magistrate also made reports about the city's financial and social state. ${ }^{140}$ The Citizens' Committee itself, meanwhile, was still drowning in internal problems, without taking a decision on which direction to turn. At the end of January, at one of the meetings, Bronisław Krzyżanowski made a draft proposal for the introduction of the Polish language into the structures of the city's Board, credit societies of the city, and the private Merchants' Bank of Vilnius. The proposal was approved unanimously. ${ }^{141}$ The Committee again wrote a memo to the Germans, offering to revive the city's economic life through the elimination of trade barriers, and the promotion of the export and import of goods. But for this, according to the authors, first of all they had to renew the activities of the local government,

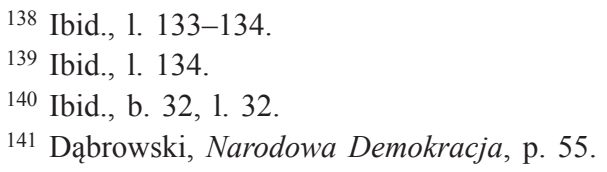


and raise funds through a loan. ${ }^{142}$ And at the same time, the Polish members of the Committee were creating yet another purely Polish social and political organisation, the Vilnius Chief National Committee, to replace the Citizens' Committee, which was falling apart, and possibly represent Polish interests more effectively. ${ }^{143}$ Disappointed with the activities of the Citizens' Committee, the representatives of other nationalities also rapidly formed purely national closed public political representations. ${ }^{144}$ On the other hand, the non-Polish members of the Citizens' Committee did not rush to liquidate it, considering that the possibilities of the Committee, as a representation that was officially recognised by the Germans, were not yet fully exhausted. ${ }^{145}$

On 20 January 1916, the city's Board asked Oberbürgermeister Pohl to increase the number of its members from four to six, on the grounds of the large workload. He replied that he would appoint as many as six new members, two each from the Poles, Lithuanians and Jews. ${ }^{146}$ This was done in the next few days. On 28 January the Citizens' Committee, by a decree from Hindenburg, was formally disbanded, ${ }^{147}$ but the Poles still did not feel any danger to their interests because of this. On the contrary, it seemed to them that good prospects were dawning for Polishness in the city. For at the first meeting of the enlarged Board on 29 January, Pohl was quite favourably disposed with regard to the initiative for changing the official record-keeping language from Russian to Polish. ${ }^{148}$ At the same time, the Poles were proud of the very successful and fruitful activities of the Education Committee in Vilnius and its surroundings.

However, on 11 February, German officials conducted a search of a Polish bookshop, and confiscated a number of patriotic books. ${ }^{149}$ This was perhaps the first obvious manifestation of the changing attitude of the Germans. The famous historian Wiktor Sukiennicki says that Ludendorff became angry after receiving information that

142 Komitet Obywatelski w Wilnie. Memoriał podany władzom niemieckim w 1916 r., LMAVB RS, f. 9-2853, 1. 5-9.

143 Dąbrowski, Narodowa Demokracja, pp. 56-58.

144 Lopata, 'Lietuvos valstybingumo raida', pp. 72-73.

145 Jankowski, Z dnia, p. 405.

${ }^{146}$ Szklennik, Dziennik, LCVIA, f. 1135, ap. 4, b. 32, 1. 30.

147 Dąbrowski, Narodowa Demokracja, p. 56.

148 Szklennik, Dziennik, LCVIA, f. 1135, ap. 4, b. 32, 1. 38.

149 Ibid., 1. 45. 
the school textbooks wrote not only about 'Polish' Vilnius, but also 'Polish' Gdansk and Poznan. ${ }^{150}$ On 21 February, the news spread that the Educational Committee was prohibited, and the courses for Polish teachers were closed, motivated by a ban on political activities. The operation of the Polish self-education 'People's University' were restricted. ${ }^{151}$ From now schools had to be managed by the same 'Basic Guidelines to Revive the School System' (Grundlegende Richtlinien zur Wiederbelebung des Schulwesens) for the whole territory of the Oberost, published on 28 January. German school inspectors were to oversee education. ${ }^{152}$ At the same time, Ludendorff 'discovered' Belarusians in the occupied territory, and decided to free Catholics among them from the influence of the Poles. In Vilnius, a favoured Belarusian newspaper supported by the Germans began to be issued, the establishment of Belarusian schools was supported, and so on. ${ }^{153}$

In parallel, Ludendorff continued and developed the actions of the centralisation and strengthening of the German administration, which Vilnius society felt immediately. On 21 February it was announced that the city's Board was becoming the 'Städtischer Beirat', an advisory institution of the city's administration, able to function only in the name of the Oberbürgermeister ${ }^{154}$ The ordinance covered the whole territory of the Oberost, and its essence was the destruction of all existing old institutions of local government. ${ }^{155}$ The concept of the German 'city governor' (Stadthauptmann) was introduced into documentation. In Vilnius, the current Oberbürgermeister Pohl had to carry out this role. To the German rulers in cities, the freedom of action to convene or not to convene an advisory council of local residents was legally provided. ${ }^{156}$ It was also not stipulated that the advisory council would become a structure in the transformed old

${ }^{150}$ Sukiennicki, 'Początki Ober-Ostu', p. 101.

151 Szklennik, Dziennik, LCVIA, f. 1135, ap. 4, b. 32, 1. 54.

152 Sukiennicki, 'Początki Ober-Ostu', p. 101.

153 Ibid.

${ }^{154}$ Szklennik, Dziennik, LCVIA, f. 1135, ap. 4, b. 32, 1. 55, 61; the appropriate edict was signed by Hindenburg already on 13 February (W. Zawadski, Materialy do Komitetu Polskiego w Wilnie 1916-17, LMAVB RS, f. 9-1620, 1. 52 a.p.).

155 'Przyboczne rady miejskie', Dziennik Wileński, 16 VII 1916, no. 136, p. 1.

${ }^{156}$ Ibid. It is said that the 'city governor of the Germans can call for its control of affairs with the help of the inhabitants', 'the city governor may convene the advisory board as necessary'. It is also said that the members of the advisory board 'can at any time be removed from these duties'. 
local government. ${ }^{157}$ So it was to turn out that the Germans, in an improvised way, were aiming to turn the Board of the city of Vilnius into an advisory council. Upon receipt of this message, 41 members of the magistrate gathered informally to discuss how to proceed. After a debate, they voted for the further activities of the Board under the imposed status of the Germans, for it was stated that they only legalised the unfolding situation. ${ }^{158}$ On 23 February, the city's Board met with its new status, chaired by the German Oberbürgermeister, discussed the question of the acquisition of a loan, and formed a commission for it. ${ }^{159} \mathrm{We}$ can consider this episode as a critical moment in the activities of the magistrate during the occupation. The development of further events consistently, albeit gradually, went according to the vision of the creators of the Oberost: the hosts of the situation were inserting 'Beirat' record-keeping in stages in the German language; the cash records of the city government, its accounting, even of the employees of the magistrate were transferred from the premises of the magistrate to their own offices, it created such an oppressive and humiliating work environment for Węsławski, the head of the 'Beirat', that, not being able to handle it, he declared that he was resigning ${ }^{160}$ (the mass withdrawal and resignation of magistrate officials, and the leadership of Węsławski, took place in mid-summer of $1916^{161}$ ). The first repressions of disobedient employees also began. It is interesting and very significant that, at the same time, the functioning and activities of the 'Beirat' began almost to be isolated from the official information space. For example, A. Szklennik noted in his diary on 12 March that, about

157 Ibid. It was fixed that in cities with a population of various nations the advisory board had to be completed so that each nationality would be proportionately represented on it. The decree provides, inter alia, that the city governor and chairman of the advisory council meetings may at any time require meetings, and that in the record-keeping of the council the German language be used.

158 Szklennik, Dziennik, LCVIA, f. 1135, ap. 4, b. 32, 1. 55.

159 Ibid., 1. 62.

160 Ibid., 1. 107, 109, 117. The Germans also tried to limit significantly and to take into their control the city's militia: already after a few weeks of the occupation a reorganisation followed, erasing the public voluntary nature of the militia and making it paid by the magistrate, an institution clearly charged with it. Gradually, the Germans transformed it into a military police, assigned to the board of the German police, maintained in accordance with their own statutes. In October 1916 a mere 400 individuals comprised the police (Klimas, Dienoraštis, p. 37; 'Lietuvos gyvenimas karo metu', Mūsų kalendorius 1917 metams (Vilnius, 1916), pp. 4, 21).

${ }^{161}$ Szklennik, Dziennik, LCVIA, f. 1135, ap. 4, b. 33, 1. 72, 86-87. 
the German management, one could only write what the official Wilnaer Zeitung (Vilnius Newspaper) wrote. And it said about the city administration: 'After its occupation, the Oberbürgermeister of the Germans spontaneously took over the management of Vilnius'. Subordinate to him were the second mayor, the advisor for city construction, the advisor for the city's schools, and the inspector of Vilnius forests, belonging to the forest inspectorate. ${ }^{162}$ And ... not a word about 'Beirat' and its prehistory.

\section{Conclusions}

The turning point in the development of the Vilnius administration during the First World War was 5/18 September 1915, when the German army entered the city. The Russians abandoned Vilnius without a fight, unlike other major cities, which had a significant influence on the administration, in particular on the change of administration. Usually, as a result of fighting, the former government left the territory to its fate, but this time certain administrative structures, the city's magistrate, police and Citizens' Committee, were sanctioned for later. On the other hand, it is more correct to call that legacy a reservation, mediated by the initiatives of a strong local public.

The remaining administrative structures were in many respects very uneven: in origin, principle of formation, legal status, and the range of administration. The magistrate had the most experience in administration, its traditions and history, while the Citizens' Committee and the militia were totally newly formed, from the public needs of the moment, as well as the realities of the spontaneously arising institution. The fact that the withdrawing Russian government, to the local society, was in many ways as alien and imposed as the arriving German government, became especially clear in the extreme situation of war, and greatly complicated the whole area of administraton.

The Germans, from the very beginning, felt insecure in the city, and cared about the administration to the extent that it was directly related to their purely military interests. In Vilnius, institutions for the administration of military structures were created one after the other, leaving civilian rule in the background. Protecting the population's interests and needs was completely unregulated, but

162 Ibid., b. 32, 1. 76-77. 
the needs of the German army were clearly defined, at the expense of the local society. The Germans did not destroy the structures of civil administration they found, but tried to harness them to satisfy their own interests.

As the Germans gradually became established in the city and the surrounding area, during the first few months of the occupation, the tendency emerged by the authorities to link the future of the Vilnius region with Poland, resulting from that in favouring the Polish part of the community. The fundamentals of a certain constructive cooperation with Polish-dominated local structures were stabilised. In addition, the Germans began to build the basics of the occupying civilian administration, cadres for which were once again drawn from the local Poles.

The specifics of the Vilnius administration were such that there were institutions in the city designed and provided for the administration not only of the city itself, but also of the surrounding region; and this was directly related to the traditional image of Vilnius as the country's capital, or at least a major regional centre. Sometimes the territorial competence of these institutions was not clearly defined, it depended on the situation, as in the case of the Citizens' Committee. It is very interesting that this is characteristic of both local and German institutions. Sometimes a space was deliberately formed for different interpretations (e.g., the informational juggling by the Germans on the concept of the gubernia). Administrative matters were turned into part of a wide political and geopolitical game. All this made the administrative situation in Vilnius extremely confusing and difficult for the local population to comprehend, and ineffective in the practice of the administrators themselves. Among the institutions of local origin, there was an unhealthy rivalry and tension.

The Poles of Vilnius hoped for the establishment of a civil administration and clarity of management procedures based on the example of the German-occupied lands of the ethnic Poles. However, the German supreme military command in the East had a different vision of the future of the occupied country. According to it, Vilnius and the surrounding region were to become part of a special, equally standardised and regulated territorial unit of the Oberost. In the short term, the role of economic and military colony of Germany was foreseen for this unit. Oberost initiator General Ludendorff began to realise his idea in the late autumn of 1915, and one of his 
first steps was to apply an anti-Polish policy. A civil administration began to be created on a purely German military basis, in parallel taking on full control of the administrative authorities of local origin that were consistently being narrowed and squeezed. In Vilnius, the process got under way at the very beginning of 1916, but there was a certain cut-off point on the abolition of the autonomy of the city's magistrate, carried out by the Germans at the end of February, and its conversion essentially into an institution of another nature.

Author Details.

Edmundas Gimžauskas, a doctor of humanities, is a researcher in the 20th Century History Department of the Lithuanian Institute of History. His main academic interests are: Lithuania's ethnopolitical history in the first half of the 20th century; preparing the publication of 20th-century; sources of Lithuania's history.

Address: Lithuanian Institute of History, Kražių g. 5, Vilnius LT-01108

E-mail: e.gimzauskas@yahoo.com

\section{References}

COLLIANDER, B. Die Beziehungen Lithuania zwischen Deutschland und der während Okkupation 1915-1918 (Abo, 1935).

ČEPĖNAS, P. Naujuju laiku Lietuvos istorija, t. 2 (Vilnius, 1992).

DĄBROWSKI, P. Narodowa Demokracja byłego Wielkiego Księstwa Litewskiego. Studium z zakresu myśli politycznej i działalności obozu narodowego na ziemiach litewsko-białoruskich w latach 1897-1918 (Kraków, 2010).

DĄBROWSKI, P. Siła w kulturze, jedność w narodzie. Wileńska działalność społeczno-polityczna Michała, Witolda i Emilii Węsławskich końcu XIX wieku i pierwszej połowie XX stulecia (do 1930 roku) (Gdańsk, 2011).

Das Land Ober Ost. Deutsche Arbeit in den Verwaltungsgebieten Kurland, Litauen und Bialystok-Grodno (Stuttgart, 1917).

DONIELA, V. 'Vilniaus kritimas 1915 metais', in Paštas ir filatelija Lietuvoje, 43 (1999).

EIDINTAS, A. 'Lietuvių ir vokiečių santykių tyrinèjimai XX amžiaus lietuvių istoriografijoje (Apžvalgos bandymas)', in EIDINTAS, A. Istorija kaip politika: ivvykiu raidos apžvalga (Vilnius, 2008).

FISCHER, F. Griff nach der Weltmacht. Die Kriegszielpolitik des kaiserlichen Deutschlands 1914-1918 (Düsseldorf, 1961).

HÄPKE, R. Die deutsche Verwaltung in Litauen 1915 bis 1918 (Berlin, 1921).

JANKOWSKI, Cz. Z dnia na dzień. Warszawa 1914-1915 (Vilnius, 1923). 
JAWORSKI, I. Zarys dziejów Wilna (Vilnius, 1929).

JUNDZIŁŁ, Z. 'Z dziejów polskiej myśli politycznej na Litwie historycznej', in Niepodległość, 6 (London, 1958).

JURGINIS, J., MERKYS, V., TAUTAVIČIUS, A. Vilniaus miesto istorija: nuo seniausiu laiku iki Spalio revoliucijos (Vilnius, 1968).

JURKIEWICZ, J. Rozwój polskiej myśli politycznej na Litwie $i$ w Białorusi latach 1905-1922 (Poznań, 1983).

KAIRYS, S. 'Nepriklausomybès akto išvakarèse', Kultūra, 2 (1938).

KLIMAS, P. Dienoraštis $19151201-191901$ 19, pradedamas P. Bugailiškio užrašais 19150823 (10)-10 13 (Chicago, 1988).

KLIMAS, P. Iš mano atsiminimu (Vilnius, 1990).

Lietuvos TSR istorija, t. 2: Nuo 1861 iki 1917 metu, ed. J. Žiugžda (Vilnius, 1963).

LOPATA, R. 'Lietuvos valstybingumo raida 1914-1918 metais', in Lietuviu atgimimo istorijos studijos, 9 (Vilnius, 1996).

ŁUBIEŃSKI, W. 'Wilno we wrześniu 1915 r.: kartki z pamiętnika sprzed 22 laty', in Kurier Wileński, 247, 8 IX 1937.

PEČIUULS, M. 'Pirmojo pasaulinio karo veiksmai Lietuvos teritorijoje 1915 m. rugpjūčio pabaigoje - rugsèjo mènesi', in Karo archyvas 25 (2010).

PUKSZTO, A. 'Postawy wileńskich Polaków pod niemiecką okupacją w latach 1915-1918', in Ostatni obywatele Wielkiego Księstwa Litewskiego, red. T. Bujnicki, K. Stępnik (Lublin, 2005).

PUKSZTO, A. 'Wilno pod koniec 1915 r. - na początku 1916. Polskie czy niepolskie?', in Przegląd Wschodni, 1(8) (2002).

SUKIENNICKI, W. 'Początki Ober-Ostu i sprawa Konfederacji W. Ks. Litewskiego w 1915-1916', in Zeszyty Historyczne, 28 (1974).

WAŁDOCH, J. 'Wybory do Rady miejskiej i Zarządu miejskiego miasta Wilna w latach 1905-1913', in Miscellanea Historico-Iuridica, 11 (2012). 
Istoriografijoje ịsitvirtinusi nuomonè, kad Pirmojo pasaulinio karo metais į Rusijos imperijai priklausiusias žemes įžengusi vokiečiu kariuomenè savas okupacines administracines struktūras kūre iš esmès tuščioje vietoje. Tai taikoma ir Vilniaus atveju. Vis dèlto ano meto ịvykių liudininkų dienoraščiai bei atsiminimai verčia suabejoti šiuo itin įsišaknijusiu stereotipu. Išties, vokiečių ịžengimas ị Vilnių 1915 m. rugsèji reiškè radikalius pokyčius miesto administravimo raidoje, tačiau atejję užkariautojai čia rado tikrai ne tuščią vietą. Buvo paliktos jau esamos tam tikros struktūros: miesto magistratas, milicija, Piliečių komitetas. Jos buvo sukurtos rusų valdžios, tačiau ne jos, o vietinès visuomenès iniciatyva. Ǐžengę vokiečiai nenaikino rastų civilinio administravimo struktūrų, bet palenké jas saviems interesams tenkinti. Greta jie kūrẻ karines struktūras, paliekančias nuošalyje civilinị valdymą. Vokiečiams pamažu ịsitvirtinant, ėmė rastis ir okupacinio civilinio valdymo pradmenys, kuriems kadru semtasi iš vietinių lenkų. Tai siejosi su pirmaisiais okupacijos mènesiais pasireiškusia Vokietijos valdžios tendencija Vilniaus regiono ateitị sieti su Lenkija. Vilniaus lenkai, dominavę civilinio administravimo struktūrose, tikejosi liberalios valdymo sistemos, analogiškos okupuotai etninei Lenkijai. Tačiau vėlų 1915 m. rudenị aukščiausios vokiečių karinès vadovybės Rytuose iniciatyva imtas kurti ypatingas administracinis darinys Oberostas, turęjęs tapti Vokietijos ekonomine bei karine kolonija. Vilniaus regionas irgi turëjo tapti jo dalimi. Nuo tada prasidejo vokiškos civilinès administracijos kūrimas grynai kariniais pagrindais, lenkiškumo slopinimas ir visų buvusių vietinių administravimo struktūrų palaipsnis varžymas ir gniaužimas, visiškai išryškèjęs jau 1916 m. pradžioje. 